\title{
建築構造物のアクティブ制御に適した等価入力外乱手法の提案 A NEW EQUIVALENT-INPUT-DISTURBANCE APPROACH FOR ACTIVE CONTROL OF BUILDINGS
}

\author{
宮本 皓*1, 佐 藤大樹*2, 佘 錦 華*3 \\ Kou MIYAMOTO, Daiki SATO and Jinhua SHE
}

\begin{abstract}
This study presented a new structure and design method for active structural control (ASC) based on the equivalent-input-disturbance (EID) approach. The method considers an absolute acceleration and relative displacement. In the last few decades, ASC has been studied widely, and some advanced control methods, such as the EID approach, was also applied for ASC. Suppressing absolute acceleration is important to protect properties and people from a large earthquake. However, previous EID control systems only considered the relative displacement but not absolute acceleration. In contrast, this study developed an extended EID control system that suppresses absolute acceleration and displacement simultaneously.
\end{abstract}

Keywords : Active-structural control, Equivalent-input-disturbance, vibration control, absolute acceleration, displacement, アクティブ制御，等価入力外乱，振動制御，絶対加速度，相対変位

1. はじめに

1995 年の兵庫県南部地震以降, 建築物の倒壊を防ぐだけでなく, 損傷も最小限にする目的としてパッシブ免震や制振を始めとするパ ッシブ制御を導入する件数が増加してきている ${ }^{11}$ 。一方で，更なる 振動制御性能を得るために, 制御工学を応用したアクティブ制御が, 日本のみならず，世界中の建築物にも適用されている ${ }^{2)}$ 。建築物の アクティブ制御に関して，現在に至るまで様々な制御手法が応用さ れており，従来の古典制御理論や現代制御理論 ${ }^{3)}$ に留まらず， $H_{\infty}$ 制 御 4)や予見制御 5)などを応用した研究も行われており, 建築物のア クティブ制御の技術は時代と共に大きな躍進を見せている。近年で は，建築物の損傷を最小限にし，内部の人を守る観点等から，絶対 加速度や層間変位を考慮した制御方法も開発されているたとえば (6) - 9) これらの研究は, 制御対象にフィードバック制御のみがつけられる 制御系であった。一方, She らにより提案された等価入力外乱 ${ }^{10)}$ (EID: equivalent input disturbance) 手法はフィードバック制御に，相 対変位や相対速度の応答を推定する状態推定器(オブザーバ)や等価 入力外乱推定器から構成されるフィードフォワード制御を更に取り 付けた制御系である。これは，フィードバック制御は制御系の固有 周期や減衰定数の改善を行い, 等価入力外乱推定器とオブザーバよ り構成されるフィードフォワード制御部分から生成される制御入力 は外乱そのものに作用しこれを抑える働きがある。このことから， 従来から用いられている状態フィードバック制御に比べ，よりよい 制御性能を得られることが期待される。

等価入力外乱手法を用いた建築物のアクティブ制御に関する既往 研究では, She らにより, 制御入力がある一定以下の場合は 0 とす る帯域, いわゆる不感帯が存在する場合での制御効果が検討された 11)。その結果, 制御入力に不感帯がある場合においても, 等価入力
外乱手法は，従来から用いられている最適制御よりも，相対変位と 相対速度に対して，よい制御性能が得られることが示された。さら に, Miyamotoらにより，等価入力外乱推定器に用いられるローパス フィルターの設計法の提案や, 等価入力外乱手法を用いた際の周波 数応答特性の改善に関する検討, さらに，制御入力のエネルギーに ついての考察が行われた ${ }^{12)}$ 。等価入力外乱は上記の研究を中心とし て，既に建築物の振動制御において応用がなされてきている。

しかし，等価入力外乱手法はメカトロニクス系を対象とした制御 方法として提案されたため，基本的に制御対象の相対変位と速度の みに着目している。She ${ }^{11}$ らと Miyamoto ${ }^{12}$ らの研究も, 従来のメカト ロニクス系のための等価入力外乱手法を準用したことにとどまり， 相対変位と相対速度の制御を主眼に置くものであった。建築物の振 動制御では，相対変位を抑え，損傷を最小限にすることも重要であ るのだが，同時に，絶対加速度に対する制御性能を悪化させないこ とも重要である。一般的に，相対変位と絶対加速度はトレードオフ の関係になっていることから，相対変位に対する制御性能を高める ことで，絶対加速度に対する性能は下がる可能性がある。現在用い られている等価入力外乱手法は絶対加速度を評価する機構になって いないため, 絶対加速度に対する制御性能の保証はない。また, メ カトロニクスシステムの制御系設計は主に相対系に着目をしている ことから, 絶対系の応答である絶対加速度を制御するには, 新たな 工夫が必要である。

また，等価入力外乱を用いた制御系を設計する際のパラメータが 制御性能に与える影響が不明である。そのため，パラメータ調整の 方法が全く不明瞭な状況で，オブザーバや状態フィードバック制御 の設計をすることが強いられているため，設計に困難がある。

本論文では，建築物の振動制御に即した形に改良するために，絶

\footnotetext{
*1 東京工業大学大学院環境 ·社会理工学院建築学系 大学院生 · 修士 (工学) (日本学術振興会特別研究員 DC2)

*2 東京工業大学末来産業技術研究所 准教授・博士 (工学

*3 東京工科大学工学部機械工学科 教授・博士 (工学)
}

Grad. Student, Dept. of Architecture and Building Engineering, Tokyo Institute of Technology, M.Eng.

Assoc. Prof., FIRST, Tokyo Institute of Technology, Dr.Eng. Prof., Dept. of Mechanical Engineering, School of Engineering, Tokyo University of Technology, Dr.Eng. 
対加速度を積極的に設計に取り入れた拡張等価入力外乱手法 (EEID: Extended EID) を提案し, 絶対加速度を考慮する等価入力外 乱の制御系の再構築を試みる。本論文では, 制御装置の配置による 影響を除外して各種設計用のパラメータが制御性能に与える影響を 陽な式で表し, 設計時のパラメータ調節を容易にすることを目的と して, 建築物とアクティブ制御装置が 1 自由度で表されるモデルを 対象とする。そして, 外乱入力チャンネル（位置）から出力までの 伝達関数を理論的に明らかにすることにより，オブザーバや状態フ イードバック制御設計時のパラメータが制御性能に与える影響を明 らかにする。これにより, 絶対加速度を考慮し, 建築物の振動制御 に適した新しい等価入力外乱手法を提案することに留まらず，パラ メータ調節の方法を明らかにし，制御系設計を大幅に容易にする。

本論文の構成を示す。 2 章では EEID の推定アルゴリズムや, 制御 系の構造の他, 基礎となる EID について述べる。3 章では, 外乱入 力から相対変位と絶対加速度までの伝達関数を明らかにし, EEID の 外乱入力メカニズムを明らかにする。4 章では 1 自由度系を対象と して設計用のパラメータが伝達関数に与える影響を理論的に明らか にする。 5 章では, EEID と EID, さらにフィードバック制御のみの 制御系を比較し，EEID の有用性を説明する。

\section{EEID 手法の説明}

\section{1 EID と EEID の概要}

アクティブ制御入力 $u(t)$ をもつ建築物の運動方程式は式(1)により 表される。

$M_{S} \ddot{x}(t)+D_{S} \dot{x}(t)+K_{S} x(t)=-M_{S}\{1\} \ddot{x}_{g}(t)+E_{u} u(t)$

ここで, $x(t)$ は各層の相対変位より構成されるべクトルであり, $M_{S}$ は 質量マトリックス, $D_{S}$ は減衰係数マトリックス, $K_{S}$ は剛性マトリッ クス, $\ddot{x}_{g}(t)$ は地動加速度であり， $E_{u}$ はアクチュエータの位置を表 すマトリックスである。

はじめに，式(1)を式(2)で表される状態方程式に変換する。

$$
\dot{z}(t)=A z(t)+B u(t)+B_{d} d(t)
$$

ここで,

$$
\left\{\begin{array}{lc}
z(t)=\left[\begin{array}{c}
x(t) \\
\dot{x}(t)
\end{array}\right], & A=\left[\begin{array}{cc}
0 & I \\
-M_{S}^{-1} K_{S} & -M_{S}^{-1} D_{S}
\end{array}\right], \\
B=\left[\begin{array}{c}
0 \\
M_{S}^{-1} E_{u}
\end{array}\right], & B_{d}=\left[\begin{array}{c}
0 \\
-\{1\}
\end{array}\right], \\
d(t)=\ddot{x}_{g}(t) . &
\end{array}\right.
$$

である。本論文では, $z(t)$ を制御対象の状態と呼ぶ。

式(2)をブロック線図を用いて表したものが図 1 である。

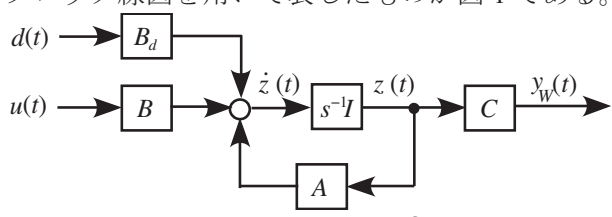

Fig. 1 Block diagram of $\mathrm{Eq}(2)$

ここで, $d(t)$ は外乱である。 $B_{d}$ は外乱入力マトリックスであり，外乱 が入力されるチャンネルを表す。また， $B$ は制御入力マトリックス であり，制御力が入力されるチャンネルである。 $A$ は制御対象の動 特性を表すシステムマトリックスである。C は出力マトリックスで ある。 $s$ はラプラス演算子を表す。また, $y_{\mathrm{w}}(t)$ は出力であり, 次
式により与えられる。

$$
y_{\mathrm{W}}(t)=C z(t)
$$

なお， $(A, B)$ は可制御， $(A, C)$ は可観測であるとする。

次に, 外乱と制御入力が，制御入力チャンネル $B$ から入力され る場合のシステムを考え，それを図２に示す。

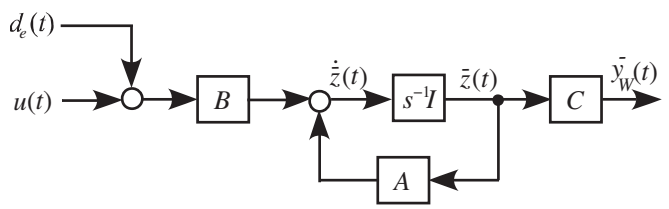

Fig. 2 System with EID

ここで， $d_{e}(t)$ は制御入力チャンネルから入力される外乱であり， この時の状態を $\bar{z}(t)$ とし，出力を $\bar{y}_{w}(t)$ とする。

図 1 と 2 について, $\bar{y}_{\mathrm{W}}(t)=y_{\mathrm{W}}(t)$ が成り立つとき, $d_{e}(t)$ を $d(t)$ の 等価入力外乱と呼ぶ。なお， $\bar{y}_{\mathrm{W}}(t)$ の位相は $y_{W}(t)$ と同じであること から， $d_{e}(t)$ の逆位相の信号を図 1 中の $u(t)$ に用いることにより，外 乱による出力における応答を抑制することができる。例えば, $C=\left[\begin{array}{ll}I & 0\end{array}\right]$ と設定することで変位を出力することから, 制御系はこれ を抑える EID を推定し，用いるものになる。

建築物の振動制御には絶対加速度を抑えることが重要である。し かし，式(3)から分かるように絶対加速度は制御対象の状態ではない ため, 式(2)の状態方程式を用いて出力するには何らかの工夫が必要 である。本論文では，式(1)に注目し，それを文献 6),7)と同様に，状 態 $(x(t), \dot{x}(t))$ と制御入力 $(u(t))$ を用いて式(5)のように表す。

$$
\ddot{x}(t)+\ddot{x}_{g}(t)=-M_{S}^{-1} D_{S} \dot{x}(t)-M_{S}^{-1} K_{S} x(t)+M_{S}^{-1} E_{u} u(t)
$$

これにより制御対象の状態 $z(t)$ と制御入力 $u(t)$ の組み合わせを用い て絶対加速度出力は次式のように表すことができる。

$$
\begin{aligned}
& y(t)=C z(t)+D u(t) \\
& C=\left[\begin{array}{ll}
-M_{S}^{-1} K_{S} & -M_{S}^{-1} D_{S}
\end{array}\right], \quad D=M_{S}^{-1} E_{u}
\end{aligned}
$$

ここで， $D$ は直達項と呼ばれる。以上より，直達項 $D$ を用いること により, 絶対加速度を出力することが可能になる。以降, 直達項が ある場合の出力は $y(t)$, 直達項がない場合の出力は $y_{W}(t)$ とする。 この時の状態方程式は, 絶対加速度を抑える等価入力外乱 $d_{e}(t)$ を用 いて式(8)により示される。また図 3 は式(8)をブロック線図で表した ものである。

$$
\left\{\begin{array}{l}
\dot{z}(t)=A z(t)+B\left[u(t)+d_{e}(t)\right] \\
y(t)=C z(t)+D u(t)
\end{array}\right.
$$

図 3 中の $d_{e}(t)$ は本論文により提案される, 絶対加速度を考慮した 新しい等価入力外乱（EEID）であり，これを求め，制御に用いるこ とで, 絶対加速度を考慮したシステムの構成が可能になる。

\section{2 絶対加速度を評価する等価入力外乱の計算方法}

制御入力チャンネル $B$ から入力する等価入力外乱 $d_{e}(t)$ を推定す

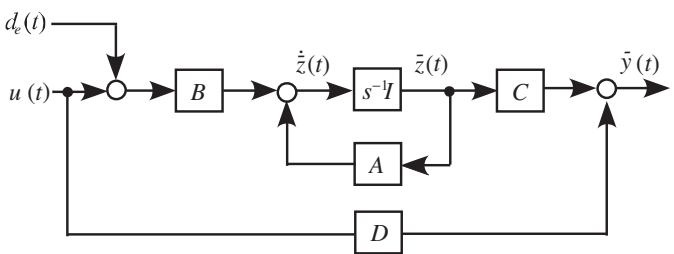

Fig. 3 System with EEID 
るためには, $B$ から出力までの伝達関数の逆数を掛けることで計算 ができる。しかし, 文献 7)上り, 多自由度系においては不安定な零 点が存在することが示唆されている。不安定な零点を有する伝達関 数の逆数は不安定な極をもつことから, 等価入力外乱の計算結果が 発散することから, 本手法を多自由度へ拡張した際の適用が困難に なることが危惧される。従って, 本論文では, オブザーバを用いる ことにより, 伝達関数の逆数を用いることなく, 等価入力外乱を推 定できるようにする。

本節では絶対加速度を考慮した等価入力外乱の計算方法を述べ る。式(8)のシステムに対する状態推定器（オブザーバ）の方程式を 式(9)に示す。

$$
\left\{\begin{array}{l}
\dot{\hat{z}}(t)=A \hat{z}(t)+B u(t)+L_{P} C[z(t)-\hat{z}(t)] \\
\hat{y}(t)=C \hat{z}(t)+D u(t)
\end{array}\right.
$$

ここで, $\hat{z}(t)$ は状態 $z(t)$ の推定值であり， $L_{P}$ はオブザーバゲインであ る。

式(8)から式(9)を減ずることで式(10)を得る

$$
\left\{\begin{array}{l}
\Delta \dot{z}(t)=\left(A-L_{P} C\right) \Delta z(t)+B d_{e}(t) \\
\Delta y(t)=C \Delta z(t)
\end{array}\right.
$$

ここで,

$$
\left\{\begin{array}{l}
\Delta z(t)=z(t)-\hat{z}(t) \\
\Delta y(t)=y(t)-\hat{y}(t)
\end{array}\right.
$$

であり, $\Delta z(t)$ はオブザーバによる推定した状態值 $\hat{z}(t)$ と真值 $z(t)$ と の誤差を表す。

一方， 2 章で述べたように， $(A, B)$ が可制御である仮定より

$$
\Delta \dot{z}(t)=A \Delta z(t)+B \Delta d(t)
$$

を満たす $\Delta d(t)$ が存在する。

式(10)に式(12)を代入することにより，式(13)を得る。

$$
B\left[d_{e}(t)-\Delta d(t)\right]=L_{P} C \Delta z(t)
$$

等価入力外乱の推定值 $\hat{d}_{e}(t)$ を, 等価入力外乱 $d_{e}(t)$ と $\Delta d(t)$ を用いて式 (14)で定義する。

$$
\hat{d}_{e}(t)=d_{e}(t)-\Delta d(t)
$$

式(14)を式(13)に代入し, 式(15b)で与えられる制御入力マトリック ス $B$ の左疑似逆行列 $B^{+}$を左から掛けることにより, 絶対加速度を制 御する等価入力外乱の推定值 $\hat{d}_{e}(t)$ は式(15a)により与えられる。なお, 左擬似逆行列は, 行列 $B$ が列フルランクであるときに存在する。従 って, 式(3)の行列 $B$ を持つ際は, 必ず存在する ${ }^{15)}$ 。

$$
\begin{aligned}
& \hat{d}_{e}(t)=B^{+} L_{p} \Delta y(t) \\
& B^{+}=\left(B^{\mathrm{T}} B\right)^{-1} B^{\mathrm{T}}
\end{aligned}
$$

制御には $\hat{d}_{e}(t)$ をローパスフィルター $F(s)$ でフィルタリングした後の 信号 $\tilde{d}_{e}(t)$ を用いる (式(16) $)^{9)}$ 。

$$
\tilde{D}_{e}(s)=F(s) \hat{D}_{e}(s)
$$

ここで， $\tilde{D}_{e}(s)$ と $\hat{D}_{e}(s)$ は， $\tilde{d}_{e}(t)$ と $\hat{d}_{e}(t)$ をそれぞれラプラス変換 した信号である。また，ローパスフィルター $F(s)$ は式(17)による。

$$
F(s)=\frac{N_{F}}{\Omega s+1}
$$

式中において， $\Omega$ はカットオフの周波数を表し， $N_{F}$ は $0<N_{F} \leqq 1 の$ 実数で表されるパラメータである。

制御入力 $u(t)$ には状態フィードバックにより与えられる $u_{f}(t)$ と, 等価入力外乱の推定值 $\tilde{d}_{e}(t)$ の逆位相を用いて表される（式(18)）。

$$
u(t)=u_{f}(t)-\tilde{d}_{e}(t)
$$

ここで, $u_{f}(t)$ は式(19)による制御即をもつ制御入力であり，全ての状 態が直接観測可能であることを仮定している。また， $K_{P}$ は状態フィ ードバックゲインであり, 例えば, LQR（Linear Quadratic Regulator） により設計される。 $K_{p}$ の設計方法については， 5 章にて述べる。

$$
u_{f}(t)=\left[\begin{array}{ll}
K_{P 1} & K_{P 2}
\end{array}\right]\left[\begin{array}{l}
x(t) \\
\dot{x}(t)
\end{array}\right]=K_{P} z(t)
$$

最終的に, EEID を用いた制御系のブロック線図は図 4 で示される。

2 章では, 絶対加速度を制御時に考慮することを目的として直達 項 $D$ があるシステムにも適用できるように拡張された等価入力外 乱である EEID を提案し，その計算方法を示した。次章では，オブ ザーバゲインとコントローラゲインのパラメータチューニングの方 法を提案することを目的として, 外乱入力チャンネル $B_{d}$ から相対変 位 $x(t)$ と絶対加速度 $\ddot{x}(t)+\ddot{x}_{g}(t)$ までの伝達関数と, 等価入力外乱を 用いた際の，外乱除去のメカニズムを明らかにする。

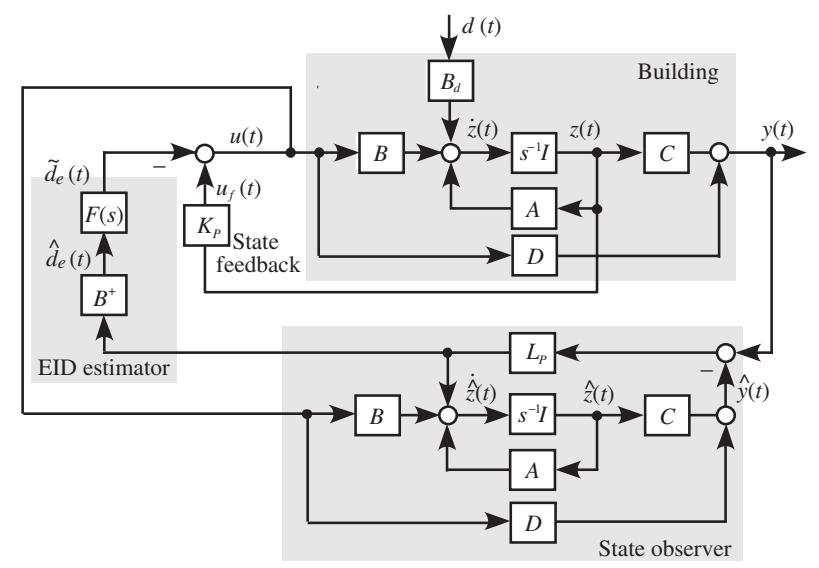

Fig. 4 Configuration of EEID system

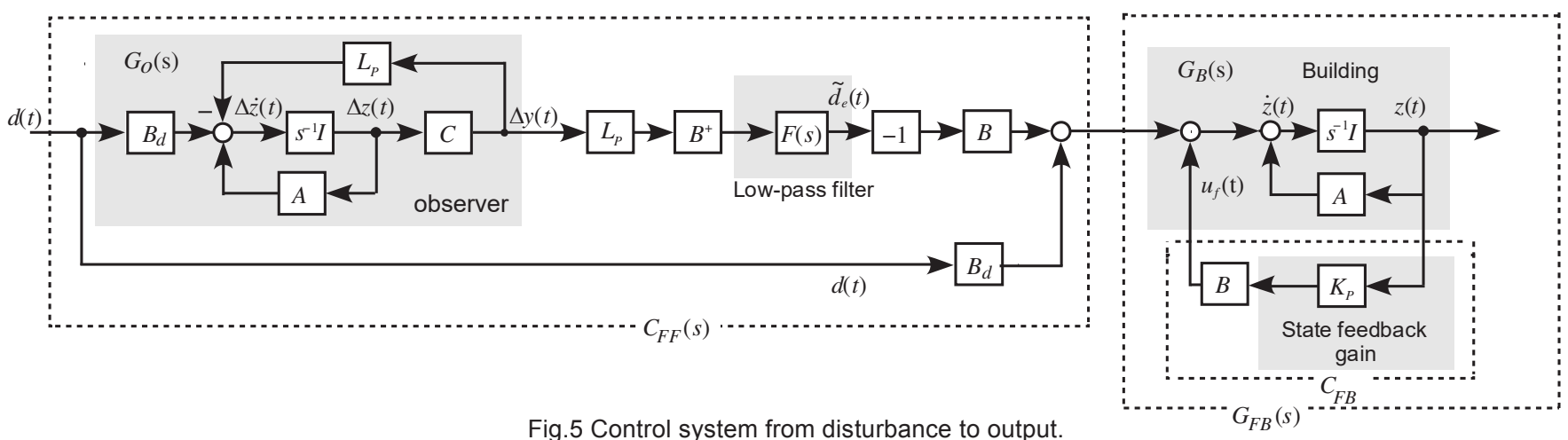


3. 外乱入カチャンネルから相対変位, 絶対加速度までの伝達関数 本章では, EEID 手法のコントローラゲイン $K_{p}($ 式(10)) オブザー バゲイン $L_{P}($ 式(9)）が外乱除去に与える影響を明らかにする。その ために, 外乱入力チャンネル $B_{d}$ から出力までの伝達関数を示す。

式(2),(10), (11), (15), (16), (17), (18)を用いて, 図 4 を図 5 のように 書き換え, 外乱入力チャンネル $B_{d}$ から状態量 $z(t)$ までの伝達関数の 考察を行う。図 5 より, 外乱入力チャンネル $B_{d}$ から入力される外乱 $d(t)$ は, 制御入力チャンネル $B$ から入力する推定等価入力外乱 $\tilde{d}_{e}(t)$ により抑えられることが分かる。また， $d(t)$ と $\tilde{d}_{e}(t)$ の差分がコン トローラゲインより生成される状態フィードバック制御入力 $u_{f}(t) に$ よって, さらに抑えられていることも分かる。

次に本制御系の特性について述べる。図 5 より, 本制御系は, 外 乱に対して, 式(20)により与えられるフィードフォワード制御部分 $C_{F F}(s)$ と, 式(21)により与えられるフィードバック制御部分 $C_{F B}$ から 構成される構造となっていることが分かる。

$$
\begin{aligned}
& C_{F F}(s)=B_{d}-B F(s) B^{+} L_{P} G_{o}(s) \\
& C_{F B}=B K_{P}
\end{aligned}
$$

ここで,

$G_{o}(s)=C\left[s I-\left(A-L_{P} C\right)\right] B_{d}$

である。フィードバック制御のみから構成される制御系では, フィ ードバック制御部分のみを用いて動特性と応答の改善をしている。 これに対し，本制御手法は，フィードバック制御と独立にフィード フォワード制御器が外乱除去を行うことにより, 従来のフィードバ ック制御よりも良い外乱除去性能を得られる。言い換えれば，フィ ードバック制御部分は制御対象の固有周期や減衰定数を改善する働 きがある ${ }^{13)} に$ 対し, フィードフォワード制御部分は, 外乱そのも のに作用し，抑える役割がある。

次に, 外乱入力チャンネルから相対変位 $(x(t))$ または絶対加速度 $\left(\ddot{x}(t)+\ddot{x}_{g}(t)\right)$ までの伝達関数をそれぞれ求める。制御対象の伝達 関数 $G_{B}(s)$ は式(23)により与えられる。

$$
G_{B}(s)=(s I-A)^{-1}
$$

これに対し, 状態フィードバックゲイン $K_{P}$ を持つ場合の伝達関数 $G_{F B}(s)$ は式(24)により表される。

$$
G_{F B}(s)=\left[s I-\left(A-B K_{P}\right)\right]^{-1}
$$

外乱入力チャンネルから制御対象となる建築物の状態 $z(t)$ までの伝 達関数 ${ }_{d} G_{z}(s)$ は, $G_{F B}(s)$ と $C_{F F}(s)$ を用いて式(25)で与えられる。その 際, ある行列 $M$ の逆行列が余因子行列 $\operatorname{adj}(M)$ と, 行列式 $|M|$ を用いて 式(26)で表されることを用いている。

$$
\begin{aligned}
{ }_{d} G_{z}(s) & =G_{F B}(s) C_{F F}(s)=G_{F B}(s)\left\{B_{d}-B F(s) B^{+} L_{P} G_{o}(s)\right\} \\
& =\left[s I-\left(A-B K_{P}\right)\right]^{-1}\left\{B_{d}-B F(s) B^{+} L_{P} C\left[s I-\left(A-L_{P} C\right)\right]^{-1} B_{d}\right\} \\
& =\frac{\operatorname{adj}\left(s I-A-B K_{P}\right)}{\left|s I-A-B K_{p}\right|}\left\{B_{d}-B \frac{N_{F}}{(\Omega s+1)} B^{+} L_{P} \frac{C \operatorname{adj}\left(s I-A+L_{p} C\right) B_{d}}{\left|s I-A+L_{p} C\right|}\right\} \\
& =\frac{\operatorname{adj}\left(s I-A-B K_{P}\right)}{\left|s I-A-B K_{p}\right|}\left\{B_{d}-B \frac{N_{F} B^{+} L_{P} C \operatorname{adj}\left(s I-A+L_{p} C\right) B_{d}}{(\Omega s+1)\left|s I-A+L_{p} C\right|}\right\}
\end{aligned}
$$

$$
M^{-1}=\frac{\operatorname{adj}(M)}{|M|}
$$

外乱入力チャンネルから, 相対変位までの伝達関数 ${ }_{d} G_{D}(s)$ は式(25) に左から $\left[\begin{array}{ll}I & 0\end{array}\right]$ を掛けることにより次式で与えられる。

$$
\begin{aligned}
{ }_{d} G_{D}(s) & =\left[\begin{array}{ll}
I & 0
\end{array}\right] G_{F B}(s)\left\{B_{d}-B F(s) B^{+} L_{P} G_{o}(s)\right\} \\
& =\left[\begin{array}{ll}
I & 0
\end{array}\right]_{d} G_{z}(s)
\end{aligned}
$$

なお，状態フィードバック制御のみが取り付けられた際の外乱入力 チャンネル $B_{d}$ から変位 $x(t)$ までの伝達関数を ${ }_{d} G_{D, F B}(s)$ とすると,

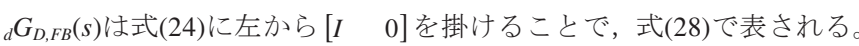

$$
{ }_{d} G_{D, F B}(s)=\left[\begin{array}{ll}
I & 0
\end{array}\right]\left[s I-\left(A-B K_{P}\right)\right]^{-1} B_{d}
$$

$$
=\left[\begin{array}{ll}
I & 0
\end{array}\right] G_{F B}(s) B_{d}
$$

式(28)は，式(27)において, $B F(s) B^{+} L_{P} G_{o}(s)=0$ の場合と一致する。 式(20)，(21)より，EEID はフィードフォワードコントローラを持ち 合わせる制御系であることを述べた。式 (27) と(28)の比較より，フ イードフォワードコントローラを搭載することで, 伝達関数中の外 乱入力チャンネル $B_{d}$ が, $\left(B_{d}-B F(s) B^{+} L_{P} G_{o}(s)\right)$ に変化することが 分かった。

次に, 地動加速度 $\ddot{x}_{g}(t)$ から絶対加速度 $\ddot{x}_{g}(t)+\ddot{x}(t)$ までの伝達関 数を求める。式(5)に, 式(18)と式(19)を代入することで式(29)が得ら れる。

$$
\begin{aligned}
\ddot{x}(t)+\ddot{x}_{g}(t) & =-M_{S}^{-1} D_{S} \dot{x}(t)-M_{S}^{-1} K_{S} x(t)+M_{S}^{-1} E_{u} u_{f}(t)-M_{S}^{-1} E_{u} \tilde{d}_{e}(t) \\
& =-M_{S}^{-1}\left\{D_{S}+E_{u} K_{P, 1}\right\} \dot{x}(t)-M_{S}^{-1}\left\{K_{S}+E_{u} K_{P, 2}\right\} x(t)-M_{S}^{-1} E_{u} \tilde{d}_{e}(t) \\
& =-M_{S}^{-1} D_{S e q} \dot{x}(t)-M_{S}^{-1} K_{S e q} x(t)-M_{S}^{-1} E_{u} \tilde{d}_{e}(t)
\end{aligned}
$$

ここで, $D_{S e q}=D_{S}+E_{u} K_{P, 1}, K_{S e q}=K_{S}+E_{u} K_{P, 2}$ である。 式(29)の $-M_{S}^{-1} D_{S e q} \dot{x}(t)-M_{S}^{-1} K_{S e q} x(t)$ は, 出力マトリックスを $C_{e q}=\left[\begin{array}{ll}-M_{S}^{-1} K_{S e q} & -M_{S}^{-1} D_{S e q}\end{array}\right]$, 外乱を $s^{2} X_{g}(s)$ とした伝達関数式(25) の出力 $y(t)$ に等しい。従って, $-M_{S}^{-1} D_{S e q} \dot{x}(t)-M_{S}^{-1} K_{S e q} x(t)$ はラプラス 逆変換 $L^{-1}$ と式(25)を用いて式(30)で表される。

$$
\begin{aligned}
-M_{S}^{-1} D_{S e q} \dot{x}(t)-M_{S}^{-1} K_{S e q} x(t) & =L^{-1}\left[C_{e q} G_{F B}(s)\left\{B_{d}-B F(s) B^{+} L_{p} G_{o}(s)\right\} s^{2} X_{g}(s)\right] \\
& =L^{-1}\left[C_{e q} G_{F B}(s) C_{F F}(s) s^{2} X_{g}(s)\right]
\end{aligned}
$$

また, $\tilde{d}_{e}(t)$ は次式により表される。

$$
\tilde{d}_{e}(t)=L^{-1}\left\{F(s) B^{+} L_{P} G_{o}(s) s^{2} X_{g}(s)\right\}
$$

従って, 式(29)中の $M_{S}^{-1} E_{u} \tilde{d}_{e}(t)$ は, $s^{2} X_{g}(s)$ を用いて式(32)によ り表すことができる。

$$
M_{S}^{-1} E_{u} \tilde{d}_{e}(t)=L^{-1}\left\{M_{S}^{-1} E_{u} F(s) B^{+} L_{P} G_{o}(s) s^{2} X_{g}(s)\right\}
$$

式(30)，(32)を式(29)に代入することで，式(33)を得る。 $\ddot{x}(t)+\ddot{x}_{g}(t)=L^{-1}\left[C_{e q} G_{F B}(s) C_{F F}(s) s^{2} X_{g}(s)\right]-L^{-1}\left\{M_{S}^{-1} E_{u} F(s) B^{+} L_{P} G_{o}(s) s^{2} X_{g}(s)\right\}$ $=L^{-1}\left\{\left[C_{e q} G_{F B}(s) C_{F F}(s)-M_{S}^{-1} E_{u} F(s) B^{+} L_{P} G_{o}(s)\right] s^{2} X_{g}(s)\right\}$

式(33)の両辺をラプラス変換し, さらに $s^{2} X_{\mathrm{g}}(s)$ で除すことで, 外乱入 カチャンネルから絶対加速度までの伝達関数 ${ }_{d} G_{a}(s)$ は次式により与 えられる。

$$
{ }_{d} G_{a}(s)=\frac{s^{2}\left\{X_{g}(s)+X(s)\right\}}{s^{2} X_{g}(s)}=C_{e q} G_{F B}(s) C_{F F}(s)-M_{S}^{-1} E_{u} F(s) B^{+} L_{P} G_{o}(s)
$$

なお，状態フィードバック制御のみを持つ制御系では，外乱入力か ら絶対加速度までの伝達関数 ${ }_{d} G_{a, F B}(s)$ は式(34)から等価入力外乱の 項 $-M_{S}^{-1} E_{u} F(s) B^{+} L_{P} G_{o}(s)$ を除外した式(35)により与えられる。

$$
{ }_{d} G_{a, F B}(s)=\frac{s^{2}\left\{X_{g}(s)+X(s)\right\}}{s^{2} X_{g}(s)}=C_{e q} G_{F B}(s) C_{F F}(s)
$$

本章では, 外乱入力チャンネルから相対変位, 絶対加速度までの 
伝達関数を明らかにした。次章では, 絶対加速度を出力する EEID $\left(C=\left[\begin{array}{ll}-M_{S}^{-1} K_{S} & -M_{S}^{-1} D_{S}\end{array}, \quad D=M_{S}^{-1} E_{u}\right.\right.$ の場合）と, 相対変位を出 力する $\mathrm{EID}$ の相対変位と絶対加速度への制御性能の違いを理論的に 明らかにする。

\section{1 自由度系を用いた EID と EEID の比較}

\section{1 対象モデル}

等価入力外乱の推定には式(15)から分かるように, 制御装置の位 置に関する行列 $(B)$ を用いることから, 多自由度系を対象とした場 合, 制御装置の配置が大きく制御性能に影響を与える。そのため, 本論文は, それらの影響を除外してEIDとEEIDの性能を比較するこ とを目的として, 図6に示すせん断型の1自由度系の検討用モデルを 用いる。なお, 図中において質量は $m_{S}$, 剛性は $k_{S}$, 粘性は $d_{S}$ とす る。この時, 状態方程式 (式(3)）の1自由度系における変数は式 (36)により与えられる。

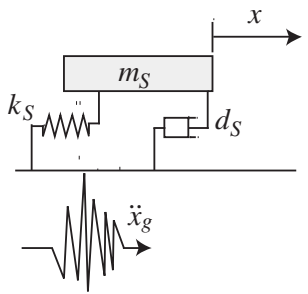

(a) Without active control

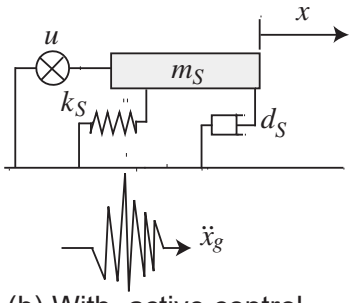

(b) With active control
Fig. 6 SDOF model

$\left\{\begin{array}{lc}z(t)=\left[\begin{array}{l}x(t) \\ \dot{x}(t)\end{array}\right], & A=\left[\begin{array}{cc}0 & I \\ -\frac{k_{S}}{m_{S}} & -\frac{d_{S}}{m_{S}}\end{array}\right] \\ B=\left[\begin{array}{c}0 \\ \frac{1}{m_{S}}\end{array}\right], & B_{d}=\left[\begin{array}{c}0 \\ -1\end{array}\right] \\ d(t)=\ddot{x}_{g}(t) & \end{array}\right.$

\section{2 アッカーマンの極配置によるオブザーバゲインの設計}

本節ではオブザーバゲイン $L_{P}$ の設計方法について述べる。推定等 価入力外乱 $\hat{d}_{e}(t)$ はオブザーバゲインと出力誤差 $\Delta y(t)$ により生成さ れることから (式(15)), オブザーバゲインの設計が制御性能を高め るために重要となる。オブザーバゲインを適切に設計することによ り, オブザーバの状態と, 観測された状態の推定誤差 $\Delta z(t) \quad$ (式(11)) を小さくし, 等価入力外乱の推定精度を高めることが可能になる。

本論文では, 図 5 中のオブザーバゲイン $L_{p}$ を双対システム ${ }^{14)}$ と アッカーマンの極配置 ${ }^{15)}$ を用いて設計を行う。これは, オブザーバ ゲインを設置した後の, オブザーバの極を $-a_{o} \pm \mathrm{j} b_{o}$ に指定する $L_{p}$ を, 式(3)の $A$ を用いて，式(37a)により計算する手法である。

$$
L_{p}=\left[\begin{array}{ll}
0 & 1
\end{array}\right] U_{C}^{-1} P(A)
$$

ここで,

$$
\begin{aligned}
& U_{C}^{\mathrm{T}}=\left[C^{\mathrm{T}} \quad A^{\mathrm{T}} C^{\mathrm{T}}\right] \\
& P(A)=\left\{A^{2}-2 a_{o} A+\left(a_{o}^{2}+b_{o}^{2}\right) I\right\}^{\mathrm{T}}
\end{aligned}
$$

$U_{C}$ は可観測性行列であり, $n$ は行列 $A$ の次元である。オブザーバの 出力を $C=\left[\begin{array}{ll}C_{o 1} & C_{o 2}\end{array}\right]$ としたとき, 1 自由度系のオブザーバゲイン $L_{P}$ は式(37b)と式(37c)に式(3)の $A$ を代入することで式(38)により算 出される。

$$
L_{p}=\left[\begin{array}{ll}
0 & 1
\end{array}\right]\left[\begin{array}{cc}
C_{o 1} & -\frac{k_{S}}{m_{S}} C_{o 2} \\
C_{o 2} & C_{o 1}-\frac{d_{S}}{m_{S}} C_{o 2}
\end{array}\right]^{-1}\left[\begin{array}{cc}
-\frac{k_{S}}{m_{S}}+a_{o}^{2}+b_{o}^{2} & -\frac{2 a_{o} d_{S}}{m_{S}}+\frac{d_{S} k_{S}}{m_{S}} \\
2 a_{o}-\frac{d_{S}}{m_{S}} & -\frac{k_{S}}{m_{S}}+\frac{d_{S}^{2}}{m_{S}^{2}}-2 a_{o} \frac{d_{S}}{m_{S}}+a_{o}^{2}+b_{o}^{2}
\end{array}\right]
$$

\section{3 絶対加速度に対する性能比較}

本節では EID と EEID の外乱入力チャンネルから絶対加速度まで の伝達関数について述べる。

\section{3. 1 EID の絶対加速度に対する性能}

式(34)を用いることにより, EID の外乱入力から絶対加速度まで の伝達関数 ${ }_{d} G_{a, E I D}$ は式(39a)により表すことができる。

$$
\begin{aligned}
& \begin{aligned}
{ }_{d} G_{a, E I D}(s) & =C_{e q} G_{F B}(s) C_{F F, E I D}(s)-M_{S}^{-1} E_{u} F(s) B^{+} L_{P, E I D} G_{o, E I D}(s) \\
& =C_{e q} G_{F B}(s)\left\{B_{d}-B H_{E I D}(s)\right\}-M_{S}^{-1} E_{u} H_{E I D}(s)
\end{aligned} \\
& \text { ここで, } \\
& \quad H_{E I D}(s)=F(s) B^{+} L_{P, E I D} G_{o, E I D}(s)
\end{aligned}
$$

式(39a)より, EID の外乱入力チャンネルから絶対加速度に関する伝 達関数は, フィードフォワード制御部分 $C_{F F E E I D}(s)$ の影響を受けてい ることが分かる。式(39a)と(39b)より， $C_{F F, E I D}(s)=B_{d}-B H_{E I D}(s)$ で あり, $C_{F F E I D}(s)$ のゲインは $\left|B_{d}-B H_{E I D}(s)\right|$ により計算されることから， 伝達関数 $H_{E I D}(s)$ のゲインを適切に設定することで, $C_{F F E I D}(s)$ のゲイ ンが小さくなる。これは, 後述する外乱入力から相対変位の伝達関 数 ${ }_{d} G_{D, E I D}($ 式(46)) のゲインを低減させる働きを意味する。しかし, 式(39a)より, $H_{E I D}(s)$ は $C_{e q} G_{F B}(s)\left\{B_{d}-B H(s)\right\} の$ 外からも引かれている ことから, 相対変位のみを考慮して $H_{E I D}(s)$ のゲインを設定すると, 絶対加速度に対しての伝達関数 ${ }_{d} G_{a, E I D}$ のゲインが増大することが危 惧される。そのため, パラメータチューニングの際は絶対加速度と 相対変位のトレードオフの考慮が必要となる。

\subsection{EEID の絶対加速度に対する性能}

式(34)を用いることにより, EEID の外乱入力から絶対加速度まで の伝達関数 ${ }_{d} G_{a, E E I D}$ は式(40a)により表すことができる。

$$
\begin{aligned}
& \begin{aligned}
{ }_{d} G_{a, E E I D}(s) & =C_{e q} G_{F B}(s) C_{F F, E E I D}(s)-M_{S}^{-1} E_{u} F(s) B^{+} L_{P, E E I D} G_{o, E E I D}(s) \\
& =C_{e q} G_{F B}(s)\left\{B_{d}-B H_{E E I D}(s)\right\}-M_{S}^{-1} E_{u} H_{E E I D}(s)
\end{aligned} \\
& \text { ここで, } \\
& H_{E E I D}(s)= F(s) B^{+} L_{P, E E I D} G_{o, E E I D}(s)
\end{aligned}
$$

式(40a)より, EEID の外乱入力チャンネルから絶対加速度までの伝 達関数も, EID と同椂に, $H_{E E I D}(s)$ によるトレードオフの関係である ことが分かる。

\section{4 相対変位に対する性能比較}

式(27)で求めた外乱入力から相対変位までの伝達関数 ${ }_{d} G_{D}(s)$ を用 いて, 相対変位を出力し抑制する等価入力外乱である EID と, 絶対 加速度を出力し抑制する等価入力外乱 EEID の相対変位に対する性 能を比較する。

\section{4. 1 EID の相対変位の性能}

$C=\left[\begin{array}{ll}C_{o 1} & C_{o 2}\end{array}\right]^{\mathrm{T}}, \quad L_{P}=\left[\begin{array}{ll}L_{P, 1} & L_{P, 2}\end{array}\right]^{\mathrm{T}}$ としたとき,オブザーバの 伝達関数 $G_{o}(s)$ は, 式(22)を用いることで次式により与えられる。

$$
G_{o}(s)=C \frac{\operatorname{adj}\left(s I-A+L_{P} C\right)}{\left|s I-A+L_{P} C\right|} B_{d}=\frac{-C_{o 1}-C_{o 2} s}{\left(s+a_{o}+b_{o} \mathrm{j}\right)\left(s+a_{o}-b_{o} \mathrm{j}\right)}
$$

相対変位を出力するオブザーバを用いた場合（EID）の伝達関数 $G_{o, E I D}(s)$ は, 式(41)に $C_{o 1}=1$ と $C_{o 2}=0$ を代入することにで, 次式によ り表される。 


$$
G_{o, E I D}(s)=\frac{-1}{\left(s+a_{o}+b_{o} \mathrm{j}\right)\left(s+a_{o}-b_{o} \mathrm{j}\right)}
$$

また，相対変位を出力する場合のオブザーバゲイン $L_{P, E I D}$ はオブザ 一バ $G_{o}(s)$ の極を $-a_{o} \pm \mathrm{j} b_{o}$ としたとき, 式(38)に $C_{o 1}=1, C_{o 2}=0$ を代 入することにより次式で与えられる。

$$
L_{P, E I D}=\left[\begin{array}{c}
L_{P 1, E I D} \\
L_{P 2, E I D}
\end{array}\right]=\left[\begin{array}{c}
2 a_{o}-\frac{d_{S}}{m_{S}} \\
-\frac{k_{S}}{m_{S}}+\frac{d_{S}^{2}}{m_{S}^{2}}-2 a_{o} \frac{d_{S}}{m_{S}}+a_{o}^{2}+b_{o}^{2}
\end{array}\right]
$$

式(41)に式(44a)と(44b), さらに, 式(44c) (44d)で表される減衰係数 $h_{o}$, 固有周波数 $f_{o}$ と極 $-a_{o} \pm \mathrm{j} b_{o}$ の関係式を代入し, $m_{S}, d_{S}, k_{S}, a_{o}$ と $b_{o}$ を消去し, 制御対象の固有周波数 $f_{S}$, 減衰定数 $h_{S}$ とオブザーバの固 有周波数 $f_{o}$, 減衰定数 $h_{o}$ を用いて, 最終的に式(45)のように表すこ とができる。

$$
\begin{aligned}
& \frac{d_{S}}{m_{S}}=4 h_{S} \pi f_{S} \\
& \frac{k_{S}}{m_{S}}=4 \pi^{2} f_{S}^{2}
\end{aligned}
$$

$$
\begin{aligned}
& h_{o}=\frac{a_{o}}{\sqrt{a_{o}^{2}+b_{o}^{2}}} \\
& f_{o}=\frac{\sqrt{a_{o}^{2}+b_{o}^{2}}}{2 \pi} \\
& L_{P, E I D}=\left[\begin{array}{l}
L_{P 1, E I D} \\
L_{P 2, E I D}
\end{array}\right]=\left[\begin{array}{c}
4 \pi\left(f_{o} h_{o}-f_{S} h_{S}\right) \\
4 \pi^{2}\left(-f_{S}^{2}+4 h_{S}^{2} f_{S}^{2}-4 h_{S} f_{S} h_{o} f_{o}+f_{o}^{2} h_{o}^{2}\right)
\end{array}\right]
\end{aligned}
$$

式(45)を式(27)に代入することで, EID の外乱入力チャンネルから相 対変位までの伝達関数 ${ }_{d} G_{D, E I D}(s)$ は式(46)により与えられる。

$$
{ }_{d} G_{D, E I D}(s)=\left[\begin{array}{ll}
I & 0
\end{array}\right] G_{F B}(s) C_{F F, E I D}(s)
$$

$$
\text { ここで， } C_{F F, E I D}(s) \text { は, 式(20)に式(18)，(22)，(36)，(43)を代入するこ }
$$
とにより, 次式で与えられる。

$$
\begin{aligned}
& C_{F F, E I D}(s)=-\frac{(\Omega s+1)\left(s^{2}+2 a_{o} s+a_{o}^{2}+b_{o}^{2}\right)-N_{F} L_{P C o n, 2}}{(\Omega s+1)\left(s+a_{o}+b_{o} \mathrm{j}\right)\left(s+a_{o}-b_{o} \mathrm{j}\right)} \\
& =-\frac{N_{3, E I D} s^{3}+N_{2, E I D} s^{2}+N_{1, E I D} s+N_{0, E I D}}{(\Omega s+1)\left(s+a_{o}+b_{o} \mathrm{j}\right)\left(s+a_{o}-b_{o} \mathrm{j}\right)} \\
& \left\{\begin{array}{l}
N_{3, E I D}=\Omega \\
N_{2, E I D}=2 a_{o} \Omega+1 \\
N_{1, E I D}=a_{o}^{2} \Omega+b_{o}^{2} \Omega+2 a_{o} \\
N_{0, E I D}=a_{o}^{2}+b_{o}^{2}-L_{P 2, E I D}
\end{array}\right.
\end{aligned}
$$

式(48)を制御対象の固有周波数 $f_{S}$, 減衰定数 $h_{S}$ とオブザーバの固有 周波数 $f_{o}$, 減衰定数 $h_{o}$ で表すと $N_{0, E I D} \sim N_{3, E I D}$ は式(49)ようになる。

$$
\left\{\begin{array}{l}
N_{3, E I D}=\Omega \\
N_{2, E I D}=4 \pi f_{o} h_{o} \Omega+1 \\
N_{1, E I D}=4 \pi f_{o}\left(\pi f_{o} \Omega+h_{o}\right) \\
N_{0, E I D}=4 \pi^{2} f_{o}^{2}-L_{P 2, E I D}
\end{array}\right.
$$

式(49)より, オブザーバゲイン LP,EID が影響しているのはラプラス変 換の演算子である $s$ の 乗である（定数項である） $N_{0, \mathrm{EID}}$ のみである ことが分かる。また, $s$ の 3 乗の項目の係数 $N_{3, E I D}$ は式(17)で表され るローパスフィルターのカットオフ周期である $\Omega$ が掛けられてい ることから， $\Omega$ の值を小さくすることにより, 高周波数成分の影響 を減少させることが可能であることが分かる。

\section{4. 2 EEID の相対変位の性能}

EEID に用いられるオブザーバの伝達関数 $G_{o E E I D}(s)$ は, 式(41)に $C_{o 1}=-k_{S} / m_{S}$ と $C_{o 2}=-d_{S} / m_{S}$ を代入することで, 次式により与えら れる。

$$
G_{o, E E I D}(s)=\frac{\frac{k_{S}}{m_{S}}+\frac{d_{S}}{m_{S}} s}{\left(s+a_{o}+b_{o} \mathrm{j}\right)\left(s+a_{o}-b_{o} \mathrm{j}\right)}
$$

一方, 絶対加速度を出力とする EEID のオブザーバゲイン $L_{P, E E I D}$ は 式(38) に $C_{o 1}=-k_{S} / m_{S}$ と $C_{o 2}=-d_{S} / m_{S}$ を代入することにより, 次式 で表される。

$$
L_{P, E E I D}=\left[\begin{array}{c}
L_{P 1, E E I D} \\
L_{P 2, E E I D}
\end{array}\right]=\left[\begin{array}{c}
\frac{m_{S} d_{S}}{k_{S}^{2}}\left(a_{o}^{2}+b_{o}^{2}\right)-2 a_{o} \frac{m_{S}}{k_{S}} \\
1-\frac{m_{S}}{k_{S}}\left(a_{o}^{2}+b_{o}^{2}\right)
\end{array}\right]
$$

式(43)から式(45)への変換と同様の手順で, 式(44a)と(44b), さらに, 式(44c) (44d)で表されるオブザーバの減衰係数 $h_{o}$, 固有周波数 $f_{o}$ と 極 $-a \pm \mathrm{j} b$ の関係式を式(51)に代入し， $m_{S}, d_{S}, k_{S}, a_{o}$ と $b_{o}$ を消去し, 制御対象の固有周波数 $f_{S}$, 減衰定数 $h_{S}$ とオブザーバの固有周波数 $f_{o}$, 減衰定数 $h_{o}$ を用いて, 最終的に式(52)のように表すことができる。

$$
L_{P, E E I D}=\left[\begin{array}{c}
L_{P 1, E E I D} \\
L_{P 2, E E I D}
\end{array}\right]=\left[\begin{array}{c}
\frac{f_{o}}{\pi f_{S}^{2}}\left(\frac{f_{o} h_{S}}{f_{S}}-h_{o}\right) \\
1-\frac{f_{o}^{2}}{f_{S}^{2}}
\end{array}\right]
$$

EEID での外乱入力から相対変位までの伝達関数 ${ }_{d} G_{D, E E I D}(s)$ も, EID と同様に，式(53)によって与えられる。

$$
{ }_{d} G_{D, E E I D}(s)=\left[\begin{array}{ll}
I & 0
\end{array}\right] G_{F B}(s) C_{F F, E E I D}(s)
$$

ここで， $C_{F F, E E I D}(s)$ は，式(20)に式(18)，(22)，(36)，(51)を代入するこ とにより，次式で与えられる。

$$
\begin{aligned}
C_{F F, E E I D}(s) & =\frac{(\Omega s+1)\left(s^{2}+2 a_{o} s+a_{o}^{2}+b_{o}^{2}\right)-N_{F} L_{P 2, E E I D}\left(-\frac{d_{s}}{m_{S}} s-\frac{k_{S}}{m_{S}}\right)}{(\Omega s+1)\left(s+a_{o}+b_{o} \mathrm{j}\right)\left(s+a_{o}-b_{o} \mathrm{j}\right)} \\
& =-\frac{N_{3, E E I D} s^{3} P+N_{2, E E I D} s^{2}+N_{1, E E I D} s+N_{0, E E I D}}{(\Omega s+1)\left(s+a_{o}+b_{o} \mathrm{j}\right)\left(s+a_{o}-b_{o} \mathrm{j}\right)}
\end{aligned}
$$

ここで,

$$
\left\{\begin{array}{l}
N_{3, \text { EEID }}=\Omega \\
N_{2, \text { EEID }}=2 a_{o} \Omega+1 \\
N_{1, \text { EEID }}=a_{o}^{2} \Omega+b_{o}^{2} \Omega+2 a_{o}+N_{F} \frac{d_{S}}{m_{S}} L_{P 2, E E I D} \\
N_{0, E E I D}=a_{o}^{2}+b_{o}^{2}+N_{F} \frac{k_{S}}{m_{S}} L_{P 2, E E I D}
\end{array}\right.
$$

式(55)を制御対象の固有周波数 $f_{S}$, 減衰定数 $h_{S}$ とオブザーバの固有 周波数 $f_{o}$, 減衰定数 $h_{o}$ を用いて次式のように書き換える。

$$
\left\{\begin{array}{l}
N_{3, \text { EEID }}=\Omega \\
N_{2, \text { EEID }}=4 \pi f_{o} h_{o} \Omega+1 \\
N_{1, \text { EEID }}=4 \pi f_{o}\left(\pi f_{o} \Omega+h_{o}\right)+4 \pi h_{S} f_{S} L_{P 2, E E I D} \\
N_{0, \text { EEID }}=4 \pi^{2} f_{o}^{2}+4 \pi^{2} f_{S}^{2} L_{P 2, E E I D}
\end{array}\right.
$$

EID の伝達関数の分子項目での係数と同様に, 式(53)より, $s$ の 3 乗 項の係数 $\left(N_{3, E E I D}\right)$ は, 式(18)で表されるローパスフィルターのカッ トオフ周期である $\Omega$ が掛けられている。これにより, EID と同様に, 
$\Omega$ の值を小さくすることで, 高周波数成分の影響を減少させること が可能である。オブザーバゲイン $L_{2 P, E E I D}$ は, EID (式(47)) と同様に, 定数項 $\left(N_{0, E E I D}\right)$ に影響することのみならず, さらに， $s$ の 1 乗の 係数である $N_{1, E E I D}$ にも影響することが分かる。式(49)より, オブザ 一バの固有周波数 $f_{o}$ を $f_{o}>\sqrt{f_{S} / \pi}$ を満たすように設計することで $L_{P 2, E E I D}$ は負になる。このとき, $N_{1, E E I D}<N_{1, E I D}$ となり $s$ の 1 次の係数 はEID よりも低くすることができ, 応答性能を改善することができ る。即ち, EID では減少させることができない $s$ の 1 乗の係数の值 も EEID では減少させることができる。 $s=\mathrm{j} \omega$ を代入した場合を考 慮すると, EEID は EID よりも, 特に低周波数で, よい良い制御性 能が得られることが分かる。

\section{4. 3 EEID とEID の相対変位に対する性能改善比}

EID に対する EEID の伝達関数の比は式(54)に式(47)を除すること で次式にて表される。

$\frac{C_{F F, E E I D}(s)}{C_{F F, E I D}(s)}=\frac{B_{d}-B H_{E E I D}(s)}{B_{d}-B H_{E I D}(s)}=\frac{\Omega s^{3}+\left(2 a_{o} \Omega+1\right) s^{2}+N_{1, E E I D} s+N_{0, E E I D}}{\Omega s^{3}+\left(2 a_{o} \Omega+1\right) s^{2}+N_{1, E I D} s+N_{0, E I D}}$

ここで, $s=\mathrm{j} \omega$ を式(57)代入し, 周波数応答のゲインの比率を求める ことで, EID と EEID の相対変位に対する性能改善比 $\lambda_{\text {dis }}(s)$ は式(58) により求められる。

$$
\begin{aligned}
\lambda_{\text {dis }}(s) & =\frac{\left|-\mathrm{j} N_{3, E E I D} \omega^{3}-N_{2, E E I D} \omega^{2}+\mathrm{j} N_{1, E E I D} \omega+N_{0, E E I D}\right|}{\left|-\mathrm{j} N_{3, E I D} \omega^{3}-N_{2, E I D} \omega^{2}+\mathrm{j} N_{1, E I D} \omega+N_{0, E I D}\right|} \\
& =\frac{\sqrt{\left(N_{1, E E I D} \omega-N_{3, E E I D} \omega^{3}\right)^{2}+\left(N_{0, E E I D}-N_{2, E E I D} \omega^{2}\right)^{2}}}{\sqrt{\left(N_{1, E I D} \omega-N_{3, E I D} \omega^{3}\right)^{2}+\left(N_{0, E I D}-N_{2, E I D} \omega^{2}\right)^{2}}}
\end{aligned}
$$

\section{5. 数值例}

本章では, 1 自由度系を制御対象とした周波数応答図を示し, 分 析を行う。本章では, 制御なしの NC, 図 5 で与えられる状態フィ ードバックゲイン $K_{p}$ のみが取り付けられたモデルである $\mathrm{FB}$, 相対 変位を出力する等価入力外乱である EID と, 本論文で提案する制御 方法である等価入力外乱である EEID の 4 種類のモデルについて比 較する。解析において, 制御対象の固有周波数 $f_{S}$ は $0.5,1.0,2.0 \mathrm{~Hz}$ の 3 種類を用いた。また制御対象の減衰定数 $h_{S}$ は 0.02 とした。ロー パスフィルターのパラメータは $\Omega$ を小さくすることで, 高周波数成 分をカットできることから， $\Omega=0.01, N_{f}=1.0$ とした。

\section{1 LQR による状態フィードバックゲインの設計}

コントローラゲインの設計には最適制御(LQR: Linear quadratic regulator)を用いて, 式(59)で与えられる評価関数を最小化するよう に決定する。

$$
J=\int_{0}^{\infty}\left\{z(t)^{\mathrm{T}} W z(t)+u(t)^{\mathrm{T}} R u(t)\right\} d t
$$

ここで, $W$ は式(60)で与えられる正定行列の重みであり, $R$ は正の スカラーである。

$$
W=\left[\begin{array}{cc}
q_{1} & 0 \\
0 & q_{2}
\end{array}\right]
$$

ここで, $q_{1}(>0), q_{2}(>0)$ は $W$ 中のパラメータである。

また, 図 5 中の状態フィードバックゲイン $K_{P}$ は次式で与えられる。 $K_{P}=-R^{-1} B^{\mathrm{T}} P$
ただし $P$ は式(62)のリカッチ方程式を満たす正定対称解である。

$A^{\mathrm{T}} P+P A+Q-P B R^{-1} B^{\mathrm{T}} P=0$

なお, 等価固有周波数 $f_{e q}$ と等価減衰定数 $h_{e q}$ に与える影響は, $q_{1}$ と $q_{2}$ を用いてそれぞれ，次式により与えられる ${ }^{14)}$

$$
\begin{aligned}
& f_{e q}=\frac{1}{2 \pi} \sqrt{\frac{k_{S}^{2}+q_{1} R^{-1}}{m}} \\
& h_{e q}=\frac{1}{4 m \pi f_{e q}} \sqrt{c_{S}^{2}+q_{2} R^{-1}-2 m_{S} k_{S}+2 \sqrt{m_{S}^{2} k_{S}^{2}+m_{S}^{2} q_{1} R^{-1}}}
\end{aligned}
$$

図 5 の $C_{F F}(s)$ の設計には, 式(63)と式(64)を用いて目標の固有周波 数, 減衰定数になるように重み $q_{1}$ と $q_{2}$ を選択する。本論文では, $f_{e q}$ $=1.5 \mathrm{~Hz}, h_{e q}=0.2$ になるように式(63)，(64)を用いて FB， EID およ びEEIDの $q_{1}$ と $q_{2}$ と $R$ を選択した (付録 $\mathrm{A}$ 参照)。

\section{2 極配置によるオブザーバゲインの設計}

4.2 節で述べたように, オブザーバの減衰定数 $h_{o}$ を高めることは, 状態の推定誤差 $\Delta z(t)$ を低減させる働きがある。推定等価入力外乱は 外乱 $d(t)$ がオブザーバに入力した際の出力を元にして推定されてい ることから (図 5), 状態の推定誤差を抑えることは, 等価入力外乱 の推定精度を高め, 外乱を正確に除去できる役割を持つ。一方で, オブザーバの減衰定数を高く設定しすぎることにより，制御力が大 きくなることが既往研究より明らかになった ${ }^{16)}$ 。さらに, 4.4.2 節で 述べたように, EEID に対してはオブザーバの固有周波数 $f_{o}$ を $f_{o}>\sqrt{f_{s} / \pi}$ と設定することが望ましかった。本論文では, これらの オブザーバの減衰定数やオブザーバの固有周波数と等価入力外乱の 推定精度を考慮し，オブザーバの有周波数 $f_{o}$ と減衰定数 $h_{o}$ がそれぞ れ $f_{o}=200 \mathrm{~Hz}, h_{o}=0.6$ になるように式(44c) と (44d)により $a_{o}$ と $b_{o}$ を決 定した。

\section{3 外乱入力から絶対加速度の伝達関数の応答比較}

NC, FB, EID および EEID の外乱入力チャンネルから絶対加速度 までの伝達関数の周波数応答図を図 7 に示す。図 7 より, FB は, $\mathrm{NC}$ よりも共振時での応答を低減していることが分かる。EID と EEID では, FBよりもさらに共振時の応答を低減していることが分 かる。また, EID と EEID は絶対加速度に対しては同等の性能を持 ち合わせることも分かった。

\section{4 外乱入力から相対変位の伝達関数の応答比較}

図 8 に NC, FB, EID および EEID の外乱入力チャンネル $B_{d}$ から, 相 対変位 $x(t)$ までの伝達関数の周波数応答図を示す。なお, $\mathrm{NC}$ の伝 達関数は付録 $\mathrm{B}$ に記した。

式(64)より, 状態フィードバック制御のみを持つ FB は制御対象の等 価減衰定数を操作寸ることから，共振時の応答を低減させることに とどまることが分かる（図 8(a) (c)）。これに対し等価入力外乱を用 いて, 入力される外乱そのものを抑制させる EID や EEID は低周波 数成分での応答低減も可能になる。制御対象の周波数がいずれの場 合でも, EEID は EID よりも相対変位に対して, より良い制御性能 が得られていることが分かる。 5.2 節より，低周波数に対する

絶対加速度の制御性能は, NC, FB, EID, EEID で同等であることが示 され, 図 8 より EEID は FB や EID と比較して, 低周波数に対する 応答を特に低減できることが示された。一般的に, 絶対加速度と相 対変位はトレードオフの関係になっていることから，相対変位に対 

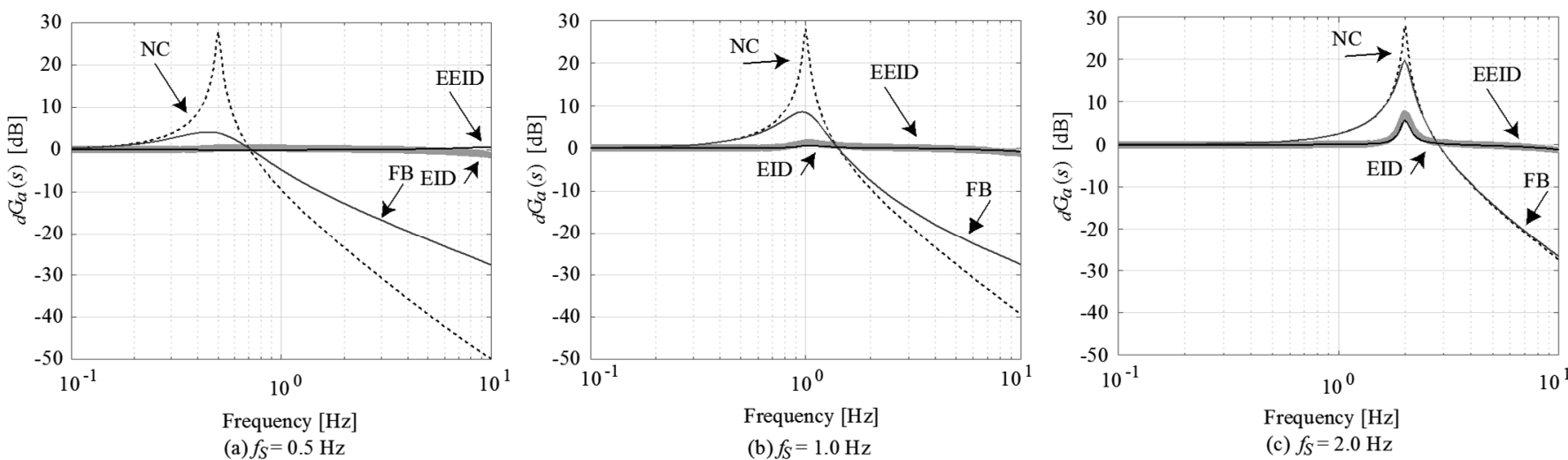

Fig. 7 Transfer function of ${ }_{d} G_{a}(s)$ of EID and EEID $\left(h_{S}=0.02\right)$

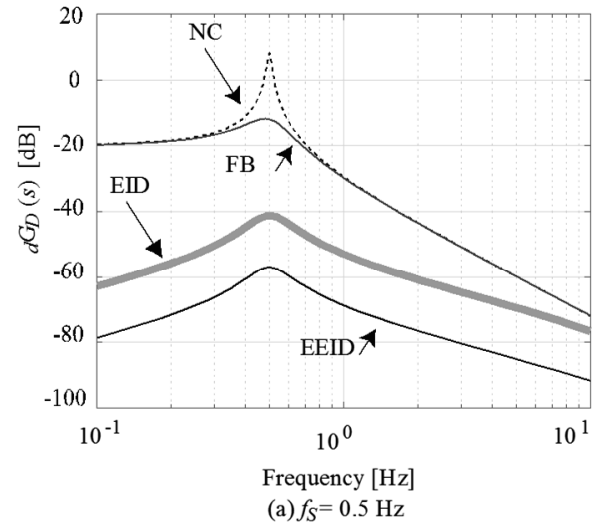

(a) $f_{S}=0.5 \mathrm{~Hz}$

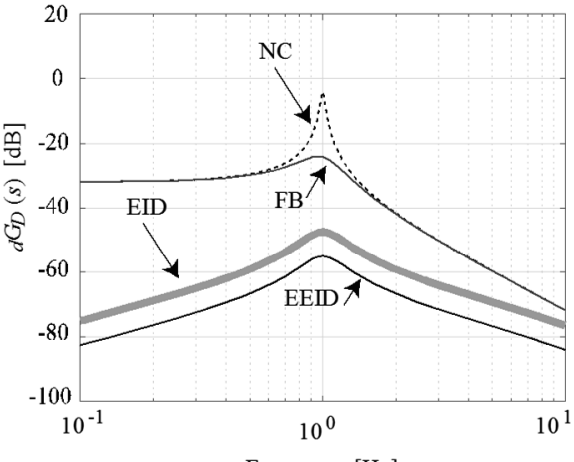

Frequency $[\mathrm{Hz}$

(b) $f_{S}=1.0 \mathrm{~Hz}$

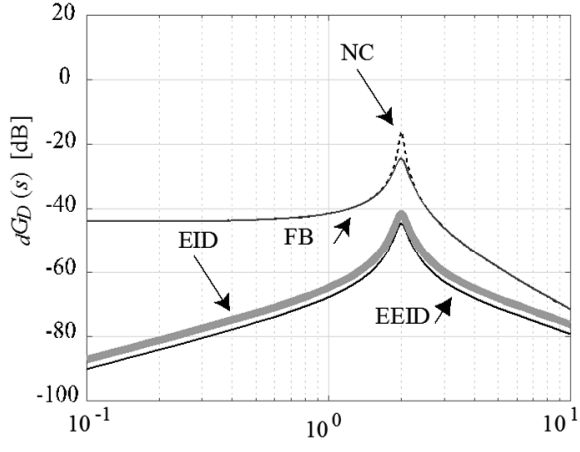

Frequency $[\mathrm{Hz}]$

(c) $f_{S}=2.0 \mathrm{~Hz}$

Fig. 8 Transfer function of ${ }_{d} G_{D}(s)$ of EID and EEID $\quad\left(h_{s}=0.02\right)$

する制御性能を高めることにより, 絶対加速度の応答は大きくなる。 EEID は絶対加速度を考慮して設計されていることから, 絶対加速 度の低周波に対するゲインを高めることなく，相対変位に対する性 能を $\mathrm{NC}$ や FB，さらに EID よりも高くすることが可能であること が示された。また, 図 8 より, 制御対象の固有周波数 $f_{s}$ が高くなる と EID と EEID の性能の差が少なくなることが分かる。この原因を 明らかにするために, 次節では, EEID と EID の性能の違いに着目 をして分析する。

\section{5 外乱入力から相対変位までの伝達関数の性能改善比曲線}

EID や EEID は FB よりも相対変位に対する制御性能がよく, 特 に, 低周波数では優れた制御性能があることが分かった。本節では, EEID と EID に焦点を絞り, 制御対象の固有周波数ごとの, 式(58) で与えられる EIDに対する EEIDの相対変位の伝達関数のゲインの 比（性能改善比） $\lambda_{\text {disp }}(s)$ について分析する。ここで, 式(58)の近似式 はマクローリン展開を用いて式(65)のように表される。

$$
\begin{aligned}
\lambda_{\text {disp }}(\mathrm{j} \omega) & =\left|\frac{\left|\Omega s^{3}+(2 a \Omega+1) s^{2}+N_{1, E I D} s+N_{0, E I D}\right|}{\left|\Omega s^{3}+(2 a \Omega+1) s^{2}+N_{1, E E I D} s+N_{0, E E I D}\right|}\right|_{S=\mathrm{j} \omega} \\
& \approx \frac{\left|N_{1, E I D}(\mathrm{j} \omega)+N_{0, E I D}\right|}{\left|N_{1, E E I D}(\mathrm{j} \omega)+N_{0, E E I D}\right|}=\frac{\sqrt{N_{0, E I D}^{2}+N_{1, E I D}^{2} \omega^{2}}}{\sqrt{N_{0, E E I D}^{2}+N_{1, E E I D}^{2} \omega^{2}}}
\end{aligned}
$$

これにより，簡便な式を用いて従来の EID との比較を, 解析を行わ ずに比較をすることが可能になり，EID では達成できなかった性能 効率を持つ制御系の設計を実現するための，オブザーバのパラメー タチューニングが容易に行える。なお，マクローリン展開を用いた
性能改善比の導出については付録 C に, 2 次と 3 次の近似式を用い て検証を行った結果とマクローリン展開については付録 D を参照 のこと。ここで, 式中の $N_{0, E I D}, N_{1, E I D}, N_{0, E E I D}, N_{1, E E I D}$ はそれぞれ式 (48)と(55)による。なお, マクローリン展開を用いて低次数の項目の みで検討することは，物理的には，低周波数のみの影響を考慮する ことを意味する。図 9 に性能改善比 $\lambda_{\text {disp }}(s)$ を示す。図 9 において, 実線は式(58)により計算された性能改善比 $\lambda_{\text {disp }}(s)$ を表し，太線は式 (65)により与えられる近似式である。図 9 より，制御対象がいずれ の固有周波数においても, 式(65)は非常に精度よく式(58)を表してい ることが分かる。

次に, 制御対象の固有周波数ごとの $s$ の 1 乗の係数である $N_{1, E I D}$ と $N_{1, E E I D}$, さらに $s$ の 乗の係数である $N_{0, E I D}$ と $N_{0, E E I D}$ の值について分

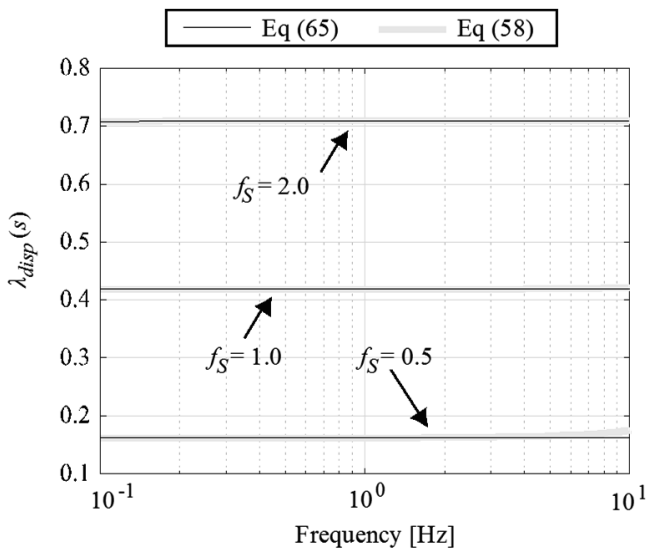

Fig. 9 Gain ratio of ${ }_{d} G_{D}(s)$ of EID and EEID 
析する。図 10 は, オブザーバの固有角周波数 $f_{o}=200 \mathrm{~Hz}$, オブザー バの減衰定数 $h_{o}=0.6$, 制御対象の減衰定数 $h_{S}=0.02$ と固定し, 制 御対象の固有角周波数 $f_{S}$ を $0.5 \mathrm{~Hz}$ から $3.0 \mathrm{~Hz}$ まで変化させた際の $N_{1, E I D} . N_{1, E E I D}, N_{0, E I D}$ および $N_{0, E E I D}$ の絶対值をプロットしたものである。

図 10 より, 值が大きく, 特にゲインへの影響が大きい $N_{1}$ の值は 制御対象の固有周波数が高くなるにつれて大きくなり, EID と EEID の差が小さくなる傾向があることが分かる。図 8 では, 制御対象の 固有周波数が高くなるごとに, EID と EEID の制御性能の差が小さ くなっていることが示された。その原因は, 制御対象の固有周波数 が高くなることにより, 特にゲインへの影響が大きい $s$ の 1 乗の係 数である $N_{1, E E I D}$ の值が大きくなることが原因であることが明らかに なった。以上の分析より, EEID は特に固有周波数が低い建築物に対 してよりよい制御性能を得られることが分かった。

\section{6. 結論}

本論文では, 従来の等価入力外乱 (EID:Equivalent Input Disturbance) では考慮していなかった絶対加速度を考慮した新しい等価入力外乱 (EEID: Extended EID) を提案し, 絶対加速度を考慮することによる 伝達関数や制御系への影響について, 理論的に考察を行った。また, 数值例では, 制御対象の固有周波数や減衰定数を変化させ, 従来の 等価入力外乱との周波数応答性能の特性の比較を行った。以下に, 本論文で得られた知見を示す。

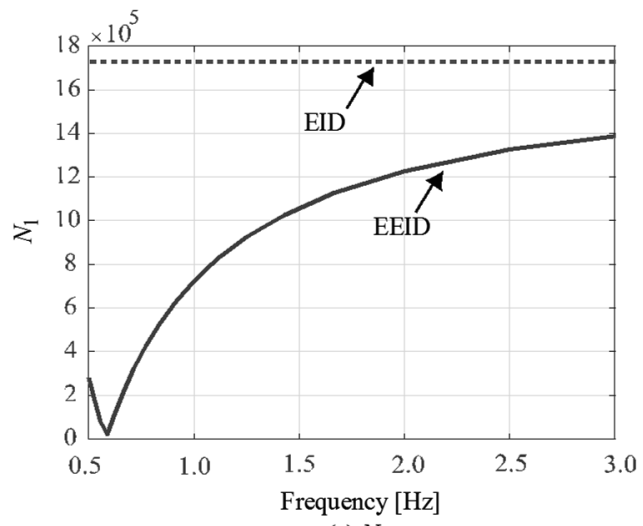

(a) $N_{1}$

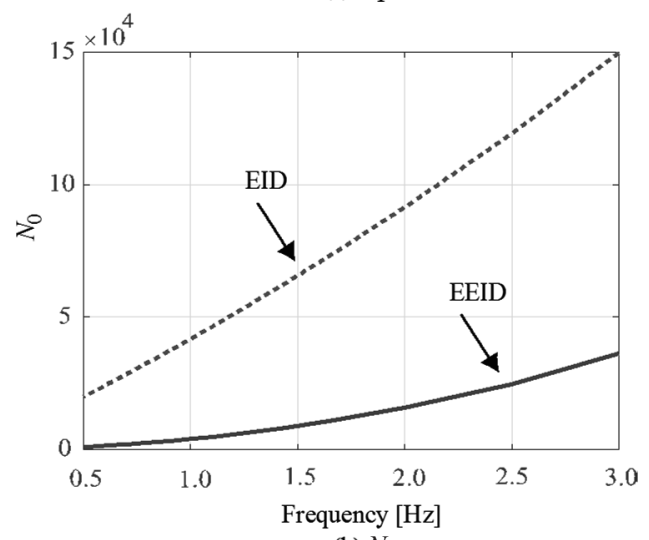

(b) $N_{0}$

Fig. $10 N_{0}$ and $N_{1}$ of EID and EEID $\left(f_{o}=200 \mathrm{~Hz}, h_{\circ}=0.6, h_{s}=0.02\right)$

・直達項を導入することにより, 絶対加速度を考慮した等価入力 外乱の構築が可能になった。

・ EEID は相対変位に対して, EID よりも性能が改善されている。
これは, フィードフォワード制御部分の伝達関数において, 従 来の等価入力外乱では干渉できない項目の值を減少させるこ とができることが原因である。

- 数值例より, EEID は従来の等価入力外乱と絶対加速度に対す る制御性能は EID とほぼ等しく保ったまま, 相対変位に対する 制御性能を改善できることが可能であることが分かった。

・ EID と EEID の伝達関数のゲイン比はマクローリン展開を用い て 1 次まで近似した式を用いることにより, 精度よく表すこと が可能であることが分かった。

・ オブザーバゲイン $L_{P}$ の分析より, EEID は制御対象の固有周波 数が低い（固有周期が長い）場合, 特に EID よりも, よい制御 性能が得られることが分かった。

本論文では，紙面の都合上，制御入力の大きさに関する考察は 述べられていない。しかし，これについて，筆者らは既に文献17） で検討を行っており, さらに詳細な考察については今後別報で示す 予定である。また, 本研究では, 理論構築のために1自由度系を用 いて解析を行った。そのため, 多自由度系への拡張も今後の課題と なる。

参考文献

1) The Japan Society of Seismic Isolation: Recent Trends in Seismic Isolation Buildings: http://www.jssi.or.jp/menshin/doc/keizoku2.pdf (in Japanese) (accessed 2018. 11.28)

2) Spencer Jr B. F., Nagarajaiah S: State of the Art of Structural control, ASCE Structural Engineering Vol. 129, pp. 845-856, 2003. 7.

3) Guclu R: Sliding mode and PID control of a structural system against earthquake, Math Comput Model, Mathematical and Computer Modeling, Vol. 44 (1-2), pp. 210-217, 2006. 7.

4) Mechbal N, Nóbrega EGO: Spatial $H_{\infty}$ approach to damage-tolerant active control. Struct Control Health Monitoring, Vol. 22, pp. 1148-1172, 2015. 9.

5) Mei G, Kareem A, Kantor JC: Model predictive control of structures under earthquakes using acceleration feedback, Journal of Engineering Mechanics Vol.128, pp. 574-585, 2002. 5.

6) Nanako Miura, Masayuki Kohiyama: Designing method of a quadratic cost function for vibration control to maintain functions of a building during an earthquake, Journal of Structural and Construction (Transactions of AIJ), Vol. 78, No. 687, pp. 923-929, 2013. 5 (In Japanese).

7) Kou Miyamoto, Daiki Sato, Jinhua She: A new performance index of LQR for combination of passive base isolation and active structural control, Engineering Structures, Vol. 157, pp.280-299. 2018. 2.

8) Akira Fukukita, Masaki Takahashi, Kazuo Yoshida: Semi-active control for isolated structures using variable damping device based on response evaluator of system, Transaction of the Japan Society of Mechanical Engineers, Series C. Vol. 75, pp. 865-873. 2009. 4 (In Japanese).

9) Kang Sungkook, Kazuo Yoshida: criterion functions and control characteristics in active vibration control, Transactions of the JSME (C-series), Vol. 58, No. 552, pp. 2373-2380, 2018, 8 .

10) She J., Xin X., and Pan Y.: Equivalent-Input-Disturbance Approach---Analysis and Application to Disturbance Rejection in Dual-Stage Feed Drive Control System, IEEE/ASME Transactions on Mechatronics, Vol. 16, pp. 330-340, 2011.3

11) She J, Sekiya K, Wu M, Lei Q: Active structural control with input dead zone based on equivalent-input-disturbance approach, Proc of 36th annual conference on IEEE industrial electronics society (IECON 2010). pp. 47-52. 2010. 11.

12) Kou Miyamoto, Jinhua She, Junya Imani, Xin Xin, Daiki Sato: Equivalentinput-disturbance approach to active structural control for seismically excited buildings, Engineering Structures, Vol. 125, pp.392-399. 2016. 10. 
13) Yinli Chen, Daiki Sato, Kou Miyamoto and Jinhua She: Equivalent model for single-degree-of-freedom model of active control. AIJ Kanto-Shibu, annual conference, 2018, 3.

陳引力, 佐藤大樹, 宮本皓, 余錦華, 1質点系モデルを対象としたアクテ イブ制御の等価モデル構築（その1：LQR重み関数の構造特性・振動特 性一の影響），日本建築学会関東支部研究報告集，2018. 3.

14) Ackerman J. E., Pole placement control: Control systems, robotics and automation, Vol. III, 2017, 7.

15) Kemin Zhou John C. Dolye and Keith Glover: Robust and optimal control, prentice hall, 1995.

16) Hitoshi Takimoto, Kou Miyamoto, Daiki Sato, Yinli Chen and Jinhua She: Estimation of Equivalent-input-disturbance by response spectrum (Part 2: Designing of feed forward part of EID system), AIJ Annual conference, 2018. 9 (In Japanese).

17) Kou Miyamoto, Daiki Sato, Yinli Chen and Jinhua She: Zettai-kasokudo ni chumoku shita Touka nyuuryoku gairan niyoru active seigyo, AIJ kanto-shibu, annual conference, 2018. 3 .

宮本皓, 佐藤大樹, 陳引力, 余錦華 : 絶対加速度制御に注目した等価 入力外乱手法によるアクティブ制御,日本建築学会関東支部研究報告 集, 2018.3 .

\section{付録 $\mathrm{A}$ 制御系設計に用いた変数}

$\mathrm{FB}, \mathrm{EID}, \mathrm{EEID}$ 中のオブザーバゲイン $L_{p}$, ローパスフィルター $F(s)$, コント ローラゲイン $K_{p}$ の設計に用いたパラメータを表 $\mathrm{A}$ に示す。

Table A. Parameters for designing FB, EID and EEID

\begin{tabular}{|c|c|c|c|c|}
\hline & $\mathrm{NC}$ & FB & EID & EEID \\
\hline$f_{S}$ & \multicolumn{4}{|c|}{$0.5,1.0,2.0[\mathrm{~Hz}]$} \\
\hline$h_{S}$ & \multicolumn{4}{|c|}{0.02} \\
\hline$q_{1}$ & & \multicolumn{3}{|c|}{$10^{4.8}$} \\
\hline$q_{2}$ & & \multicolumn{3}{|c|}{$10^{4.8}$} \\
\hline$R$ & & \multicolumn{3}{|c|}{1} \\
\hline$a_{o}$ & & \multicolumn{3}{|c|}{753.9} \\
\hline$b_{o}$ & & & \multicolumn{2}{|c|}{1005.3} \\
\hline$T$ & & & \multicolumn{2}{|c|}{0.01} \\
\hline$N_{F}$ & & & \multicolumn{2}{|c|}{1} \\
\hline
\end{tabular}

\section{付録 B NC の外乱入力から相対変位, 絶対加速度までの伝達関数}

アクティブ制御なしのモデルの, 絶対加速度は式(B1)により与えられる。 $\ddot{x}(t)+\ddot{x}_{g}(t)=-M_{S}^{-1} D_{S} \dot{x}(t)-M_{S}^{-1} K_{S} x(t)$

$$
=\left[\begin{array}{ll}
-M_{S}^{-1} K_{S} & -M_{S}^{-1} D_{S}
\end{array}\right]\left[\begin{array}{ll}
x(t) & \dot{x}(t)
\end{array}\right]^{\mathrm{T}}
$$

従って, 式(23)の左から $\left[-M_{S}^{-1} K_{S} \quad-M_{s}^{-1} D_{S}\right]$, 右から $B_{d}$ を掛けることにより $\mathrm{NC}$ の外乱から絶対加速度までの伝達関数 ${ }_{d} G_{a, N C}(s)$ は式(B2)により得られる

$$
{ }_{d} G_{a, N C}(s)=\left[-M_{S}^{-1} K_{S} \quad-M_{S}^{-1} D_{S}\right](s I-A)^{-1} B d
$$

絶対加速度から相対変位までの伝達関数 ${ }_{d} G_{a, N C}(s)$ は, 式(23)の左から

$\left[\begin{array}{ll}I & 0\end{array}\right]$, 右から $B_{d}$ をかけることにより，式(B3)により与えられる。

$$
{ }_{d} G_{a, N C}(s)=\left[\begin{array}{ll}
I & 0
\end{array}\right](s I-A)^{-1} B d
$$

\section{付録 C マクローリン展開}

ある関数 $f(x)$ のマクローリン展開は以下で定義される。

$$
f(x)=f(0)+\frac{f^{\prime}(0)}{1 !} x+\frac{f^{\prime \prime}(0)}{2 !} x^{2}+\cdots+\frac{f^{(n)}(0)}{n !} x^{n}
$$

ここで, 式(55)の分子と分母について, それぞれマクローリン展開を用いるこ とで式(A2), (A3)を得る。

$$
C_{F F, E I D}(s) \approx N_{1, E I D} s+N_{0, E I D}
$$

$C_{F F, E E I D}(s) \approx N_{1, E E I D} s+N_{0, E E I D}$

これらの值の絶対值を取り，その比率を示したものが式(65)である。

\section{付録 D マクローリン展開の次数検討}

$f_{S}=1.0 \mathrm{~Hz}, h=0.02$ のモデルを対象として, マクローリン展開時の次数の 検討を行った。その結果を図 D1 に示す。図には 0 次〜3 次までの式を表し
た。ここで，(D1) (D3)は以下の式により与えられる。

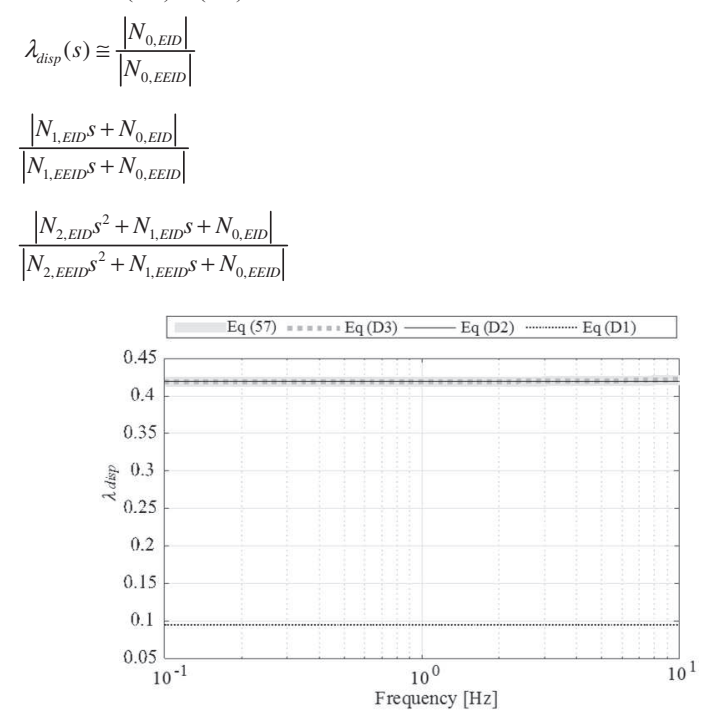

Fig. D Frequency responses for each model

図より，1 次の近似で性能改善率を十分に表すことができていることがわ ることから, 本論文では, 1 次のマクローリン展開式を用いて性能改善率の近 似式を用いた。これは, 式(45)と(52)の比較より, EEID と EIDは, ラプラス 演算子 $s$ の 2 次と 3 次の係数は同じであり, 1 次の係数と, 定数項で違いがあ

\begin{tabular}{|c|c|}
\hline$A$ & システムマトリックス \\
\hline$a_{o}$ & オブザーバの極の実部 \\
\hline$B_{d}$ & 外乱入力マトリックス \\
\hline$b_{o}$ & オブザーバの極の虚部 \\
\hline$C_{1}(s)$ & フィードフォワード制御部分 \\
\hline$D_{s}$ & 減衰マトリクス \\
\hline$d_{e}(t)$ & 等価入力外乱 \\
\hline$\hat{d}_{e}(\mathrm{t})$ & ハイズ付きの推定等価入力外乱 \\
\hline$E_{u}$ & アクチュエータの位置 \\
\hline$f_{S}$ & 制御対象の固有周波数 \\
\hline$G(s)$ & 伝達関数 \\
\hline$h_{o}$ & オブザーバの減衰係数 \\
\hline$h_{e q}$ & 等価隇衰係数 \\
\hline$J$ & $\mathrm{LQR} \sigma$ 評価関数 \\
\hline$K_{P}$ & コントローラゲイン \\
\hline$L_{P}$ & オブザーバゲイン \\
\hline$M_{S}$ & 質量マトリックス \\
\hline$P$ & リカッチ代数方程式中の変数 \\
\hline$R$ & $\begin{array}{l}\text { 評価関数Jに用いる, 制御入力に対する } \\
\text { 重み }\end{array}$ \\
\hline$t$ & 時刻 \\
\hline$W$ & 評価関数ノに用いる, 状態に対する重み \\
\hline$x(t)$ & 相対変位ベクトル \\
\hline$y(t)$ & 出力 \\
\hline$\{1\}$ & $n \times 1$ 1 のみで構成されるべクトル \\
\hline$\hat{\mathbf{n}}$ & 変数の推定值 \\
\hline
\end{tabular}
ることによるものであると考察される。

\begin{tabular}{|c|c|}
\hline$a_{s}$ & 制御対象の極の実部 \\
\hline$B$ & 制御入カマトリックス \\
\hline$b_{s}$ & 制御対象の極の虚部 \\
\hline C & 出カマトリックス \\
\hline$D$ & 直達項 \\
\hline$d(t)$ & 外乱 \\
\hline$d_{s}$ & 減衰係数 \\
\hline$\tilde{d}_{e}(\mathrm{t})$ & 推定等価入力外乱 \\
\hline$f_{o}$ & オブザーバの固有周波数 \\
\hline$f_{e q}$ & 等価固有周波数 \\
\hline$h_{s}$ & 制御対象の減衰係数 \\
\hline$I$ & 単位行列 \\
\hline$K_{S}$ & 風性マトリックス \\
\hline$k_{s}$ & 制御対象の岡性 \\
\hline$L$ & ラプラス変換 \\
\hline$m_{s}$ & 制御対象の質量 \\
\hline$q$ & 重み $W$ 中のパラメータ \\
\hline$s$ & ラプラス変換の演算子 \\
\hline$u(t)$ & 制御入力 \\
\hline$X(s)$ & $x(t)$ のラプラス変換 \\
\hline$x_{g}(t)$ & 地動変位 \\
\hline$z(t)$ & $\begin{array}{l}\text { 相対変位ベクトルとその微分である } \\
\text { 速度変位ベクトルで構成されるべク } \\
\text { トル }\end{array}$ \\
\hline$\Delta \square$ & 推定値と測定値の誤差 \\
\hline
\end{tabular}

付録 $\mathrm{E}$ 本論文で用いた変数一覧

本論文で用いた記号を表 $E$ に示す。

Table. E Nomenclature

なお，伝達関数 $G(s)$ の左下添え字は入力項を表し，右下添え字が出力項を 表す。その際, $d$ : 外乱, $D$ : 変位, $a$ : 加速度, $z$ : 状態を表し, 例えば, 外 乱から変位までの伝達関数は ${ }_{d} G_{D}(s)$ と表される。さらに, EID (変位を考慮し た等価入力外乱）での変数は右下の添え字にさらに EID と記入し, EEID（絶 対加速度を考慮した等価入力外乱）での変数は EEID と記入した。例えば, EID での外乱入力から変位までの伝達関数は ${ }_{d} G_{D}(s)_{E I D}$ となる。なお，例外と して $G_{o}(s)$ はオブザーバの伝達関数を示す。 


\author{
Kou MIYAMOTO*1, Daiki SATO *2 and Jinhua SHE ${ }^{* 3}$ \\ ${ }^{* 1}$ Grad. Student, Dept. of Architecture and Building Engineering, Tokyo Institute of Technology, M.Eng. \\ ${ }^{*}$ Assoc. Prof., FIRST, Tokyo Institute of Technology, Dr.Eng. \\ ${ }^{* 3}$ Prof., Dept. of Mechanical Engineering, School of Engineering, Tokyo University of Technology, Dr.Eng.
}

This study presents a new control system, which is an extended EID (EEID) method, for active structural control (ASC) based on the equivalent-input-disturbance (EID) approach. This method considers both the absolute acceleration and relative displacement of a building. In the last few decades, some advanced control methods are also applied for ASC. Suppressing absolute acceleration is important to protect properties and people from a large earthquake. However, conventional EID control method only considered the relative displacement but not absolute acceleration. In contrast, EEID considers both the absolute acceleration and the displacement.

Section 2 explains the EEID and EID method. This section shows the whole EEID control system, and how to calculate an EEID of a system.

Section 3 considers the transfer function of EEID from the disturbance input channel to the state of the control system. This section shows the EEID system has two control parts, which are the feedforward and feedback control parts. The feedforward part consists of the observer and the low-pass filter and the feedback control part consists of the feedback controller gain and the control input matrix.

Section 4 uses a single degree-of-freedom shear building model to compare the control performance of EID and EEID for a displacement and an absolute acceleration. This section explains that the observer gain of EID only adjusts the constant term of the transfer function of the disturbance to the displacement. In contrast, the observer gain of EEID not only influences the constant term but also the dynamic characteristic term.

Section 5 shows the results of numerical examples. This section uses three models that ordinal frequencies are 0.5, 1.0 and $2.0 \mathrm{~Hz}$ to demonstrate the validity of EEID. The results show that the control performances for absolute acceleration of NC, FB, EID and EEID are almost all the same especially for low frequency. In contrast, the results of the frequency responses for the transfer function from the disturbance to the displacement shows that the control performance for displacement of EEID is much better than that of the NC, FB and EID. There is a trade-off between the absolute acceleration and the displacement in addition to the control performance for absolute acceleration of the EEID being the same as the EID. However, despite this, the control performance for the displacement of the EEID is much better than that of the EID.

Section 6 is the conclusion of this paper. The advantages of EEID are as follow:

1) EEID consists the two control parts, which are the feedforward and feedback control parts. Thus, the control performance for displacement of EEID is much better than that of the conventional feedback control system.

2) The observer gain of EEID adjusts not only the constant term but also the dynamic characteristic term in the transfer function from the disturbance to the displacement. Thus, the control performance for displacement of EEID is much better than that of the EID.

3) There is a trade-off between the control performance for the absolute acceleration and the displacement. The control performance for displacement of EEID is much better than that of the EID while the control performance for absolute acceleration of EEID is the same as the EID. 